Caroline Oliver

\section{Retirement Migration: Paradoxes of Ageing}

New York - London: Routledge, 2013, 208 str.

DOI: 10.11567/met.29.2.8

Proces umirovljenja ima pozitivna i negativna značenja s obzirom na promjene koje izaziva $u$ životu osoba i njihovih obitelji. Jedna od pozitivnih promjena vezanih uz razdoblje umirovljenja jesu formalno oslobađanje od radnih obveza i slobodno vrijeme, koje pojedinac može provoditi na različite načine. Time se stvara mogućnost za ostvarenje životnih planova koji se prije umirovljenja nisu mogli ostvariti zbog vezanosti uz radno mjesto. Novija istraživanja o migracijskom ponašanju starijih u zapadnim društvima otkrivaju značajne razlike u odnosu na prošla desetljeća. $S$ povećanjem transnacionalne mobilnosti pitanja vremena, prostora i mjesta poprimila su nova značenja za starije osobe dajući im priliku da istraže alternativne identitete i životne stilove. Stereotipne slike starijih ljudi koji borave $\mathrm{u}$ mjestu $\mathrm{u}$ kojem su proveli najveći dio svoje odrasle dobi više ne mogu poslužiti za opis suvremene stvarnosti. Već naslov knjige Caroline Oliver upućuje na duboko ukorijenjenu sliku o migraciji u starijoj dobi kao proturječnu uobičajenom viđenju starenja.

Knjiga se dijelom temelji na istraživanju započetom 1998. za doktorski rad, koje je poslije prošireno novim istraživanjima. Tematski je usredotočena na iskustva starijih umirovljenika, »sjevernih« Europljana, većinom britanskih, koji su se odlučili preseli- tiu južnu Španjolsku u potrazi za blagom klimom, ugodnim okolišem i zadovoljstvom. Kroz osam poglavlja, 1. Introduction: Flirting with Freedom, 2. Cultural Contexts: Positive Ageing, Migration and Place, 3. Location, Location, Location: Retiring in Spain, 4. The Time of Our Lives: Temporality and the Life Course, 5. Does Age Matter? Positive Ageing and Place, 6. Community and the Individual in Migrants' Spain, 7. Cultural Identities, Ageing and Deathi, 8. Conclusion: Paradoxes of Ageing in Retirement Migration, razmatraju se temeljni pojmovi na koje je usmjereno istraživanje - starenje, umirovljenje, migracija u starijoj dobi, mjesto i identitet.

Nakon uvodnog dijela, u kojem su opisani metodologija i etnografski istraživački postupak, u drugom poglavlju autorica objašnjava kulturni kontekst u kojem su umirovljeničke migracije zamišljene kao način za postizanje ideala uspješnog starenja koji se povezuje s modernim idejama individualizma, potrošnje i putovanja. Zbog želje za postizanjem zamišljenih ideala autorica imenuje strane državljane koji žive u južnoj Španjolskoj »aspiracijskim umirovljeničkim migrantima« (str. 1). Iako se migracija vidi kao pozitivno rješenje za uspješno starenje, ona sa sobom nosi niz problema, koje Oliver opisuje kao paradokse. Paradoksi se javljaju kroz svakodnevnu društvenu i kulturnu dinamiku i kroz proces izgradnje identiteta starijih migranata te uključuje njihove odnose sa starom i novom zajednicom. Potraga za lagodnim, opuštenim životom u ugodnoj klimi, u zamišljenoj ruralnoj mediteranskoj idili, najčešće završava životom $u$ apartman- 
skim kompleksima turističkih odredišta, kako piše u drugome poglavlju, koje počinje interpretacijom intervjua vođenih sa sugovornicima koji su se doselili u Španjolsku u vrijeme prije razvoja masovnog turizma, čiji je doživljaj prostora bitno drugačiji od onih doseljenih u novijem razdoblju. Razvoj masovnog turizma, uz stihijsku urbanizaciju i razlike u cijenama zemljišta i nekretnina, koje su bile znatno niže u usporedbi sa »sjevernoeuropskim « zemljama, privukaoje brojne strane državljane. Strani umirovljenici prepoznali su pogodnosti nastale razvojem infrastrukture i boljom prometnom povezanošću kao mogućnost za život u novim područjima, što je rezultiralo koncentracijom velikog broja stranih državljana većinom na obalnim područjima koji su formiralirelativno homogene umirovljeničke zajednice. Poglavlje završava interpretacijom intervjua migranata pristiglih $\mathrm{u}$ razdoblju kada se jug Španjolske transformirao iz mediteranskoga ruralnog prostora u područje masovnog turizma. Oni daju uvid u opseg i raznolikost iskustava starijih doseljenika koji žive u Španjolskoj. Naime strani umirovljenici doživljavaju mjesto na različite načine i upozoravaju na višestruke orijentacije mjesta i zajednice u kojima žive i svoju povezanost s njima.

Vrijeme i način provođenja vremena važni su čimbenici u iskustvu starenja. Autorica u četvrtome poglavlju govori o kontradiktornim iskustvima slobodnog vremena i produktivnosti. Iskustvo slobodnog i strukturiranog vremena ukorijenjeno je $\mathrm{u}$ određenim kulturnim konceptima. Mnoge starije migrante u Španjolsku je privukla ideja lagodnog i usporenog životnog tempa, ali ih istovremeno strah od neaktivnosti potiče da se uključuju u brojne klubove, volontiraju i sudjeluju u društvenim aktivnostima koje se organiziraju za migrante. Primjeri pokazuju kako je razdoblje mirovine vrijeme za dokolicu i prigoda za postizanje zadovoljstva životom, ali i za neplaćenu produktivnost, kao što su volonterske aktivnosti za dobrobit drugih te razne aktivnosti usmjerene na obogaćivanje života. Autorica pokazuje kako se pojedinci suočavaju s različitim iskustvom vremena i kako se ono odražava na njih. U petom poglavlju ustvrđuje da preseljenje $u$ razdoblju mirovine ne utječe samo na poimanje vremena već i dobi. Migracija u novu sredinu može donijeti iskustvo starenja koje se znatno razlikuje od onoga u prethodnome mjestu stanovanja nudeći bolju kvalitetu života i nove mogućnosti za aktivnosti, relativizirajući dob i društvene konvencije. Autorica ponovno ističe paradoks migrantskog iskustva u starijoj dobi. S jedne je strane pozitivno iskustvo starenja iskazano kroz subjektivni pristup da »dob nije važna«, a s druge strane okolina može doživljavati dob kroz negativne asocijacije, temeljeći identitet migranata na sličnoj dobi. Ta napetost između stava da dob nije važna i starosti kao razdoblja života kada smo ranjiviji posebno dolazi do izražaja kada se javi bolest ili smrt partnera. Oliver nastavlja svoju raspravu o zajednici, pojedincu i imaginaciji mjesta opisujući načine na koje stariji migranti žele stvoriti novi identitet te nabrajajući prednosti i nedostatke života u zajednici. U novoj sredini umanjuje se važnost dotadašnjih životnih uspjeha i karijera na kojima su pojedinci izgradili identitete, a naglasak je na zajedničkome migrantskom statu- 
su. Jedan od primjera provjere pouzdanosti drugih ostvaruje se kroz ogovaranja i druge neformalne mreže, čime informacije o pojedincima postaju podložne višestrukom vrednovanju. Takve prakse mogu izazvati fragmentaciju zajednice, ali su i neophodne u procesu održavanja jednakosti unutar zajednice neovisnih pojedinaca (str. 114).

Kao i svi migranti koji se odlučuju na međunarodnu migraciju, oni $u$ starijoj dobi preuzimaju rizik zbog seljenja u državu s drugim jezikom, običajima, institucijama, zdravstvenim i socijalnim sustavom. Fascinacija Španjolskom sugerira da će se migranti željeti integrirati u širu zajednicu, međutim primjeri pokazuju da katkad i ne postoji namjera integriranja, već se napori usmjeruju na konstruiranje nekadašnjeg okruženja u novoj društvenoj i fizičkoj okolini. Okolina ih najčešće smatra turistima i onda kada im je neko odredište prva ili jedina adresa. Većina ipak ne prihvaća takvu identifikaciju i nastoji se razlikovati od turista. Izgradnja identiteta na temelju nacionalne baštine, kao i kozmopolitizma, uočljiva je u slučajevima smrti i pogreba u stranoj zemlji, kada okolnosti zahtijevaju usklađivanje različitih kulturnih praksi, ističe se $u$ sedmome poglavlju. Autorica u kontekstu životnog ciklusa apostrofira duboku starost i smrt, kada zajednički je- zik, kulturne prakse i poznato okruženje pomažu u prevladavanju stresnih razdoblja. Unatoč svojoj unutarnjoj heterogenosti smrt je osobito važan događaj koji starije migrante povezuje u zajednicu.

Knjiga pruža zanimljive etnografske podatke za različite znanstvene discipline, a napose je dobrodošao doprinos socijalnoj gerontologiji i sociologiji migracija. Uspješno sintetizira dva velika istraživačka područja, starenje i migracije, suprotstavljajući ideale uspješnog starenja paradoksima. Istovremeno ne pruža jednostavne odgovore na dvojbe pred kojima se nalaze stariji migranti u potrazi za pozitivnim umirovljeničkim iskustvom $\mathrm{u}$ inozemstvu. U istraživanju iskustava onih koji su sebi postavili imperativ uspješnog starenja kroz migraciju u knjizi se ističe kako pojedinci razmatraju promjene $u$ životnom ciklusu $\mathrm{u}$ vrijeme kada su prisutni sustavno stereotipiziranje i diskriminacija ljudi zbog njihove dobi. Njihovi životni stilovi i vrijednosti suprotstavljaju se dobnim predrasudama pri čemu se razdoblje mirovine vidi kao prilika za nove aktivnosti i mogućnost pronalaženja novoga smisla u svojim životima.

Mario Bara

Institut za migracije i narodnosti, Zagreb 